\title{
Pengaruh Model Pembelajaran CTL (Contextual Teaching And Learning) Terhadap Kemampuan Representasi Siswa
}

\author{
Lilis Arini $^{1}$, Nur Rahmi Rizqi ${ }^{2}$, Riska Indah Sari Lubis ${ }^{3}$ \\ ${ }^{1}$ Prodi Pendidikan Matematika, FKIP, STKIP Asy-Syafi'iyah Internasional Medan, Indonesia \\ ${ }^{2,3}$ Prodi Pendidikan Matematika, FKIP, Universitas Al Washliyah, Medan, Indonesia \\ Email: lilisarini1993@gmail.com
}

\begin{abstract}
ABSTRAK
Tujuan penelitian adalah mengetahui gambaran (1) Kemampuan representasi matematika siswa yang mengikuti pembelajaran matematika dengan model pembelajaran CTL lebih baik daripada siswa yang mengikuti model pembelajaran Konvensional, serta (2) Proses jawaban siswa terkait kemampuan representasi matematik yang diajarkan melalui model pembelajaran CTL dan Konvensional. Penelitian ini merupakan penelitian quasi experimental dengan populasi seluruh siswa kelas IX MTs PPMDH Medan Tahun Pembelajaran 2019-2020. Sampel diambil melalui teknik simple random sampling, diperoleh kelas IXA sebagai kelompok eksperimen dengan model pembelajaran CTL dan kelas IXB sebagai kelompok kontrol yang di ajar dengan model pembelajaran Konvensional (biasa). Pada akhir pembelajaran kedua kelas sampel diberi tes menggunakan instrumen yang sama yang di uji validitas, reliabilitas, taraf kesukaran dan daya pembeda. Pengumpulan data dilakukan dengan metode tes dan metode observasi. Metode tes dilakukan untuk memperoleh data nilai akhir setelah diberi perlakuan pada kelompok eksperimen dan kelompok kontrol, data dianalisis dengan uji normalitas, uji kesamaan dua varians, dan uji hipotesis menggunakan uji-t. Berdasarkan hasil perhitungan dengan menggunakan uji-t satu pihak diperoleh $t_{\text {hitung }}=5,792$ dan dengan signifikansi 0,000 . Hal ini menunjukkan 0,000 $<0,05$ maka $H_{O}$ ditolak, artinya kemampuan representasi matematik siswa yang mengikuti model pembelajaran CTL lebih baik daripada siswa yamg mengikuti model pembelajaran Konvensional. Hasil tersebut menunjukkan pembelajaran CTL berpengaruh terhadap kemampuan representasi matematik. Berdasarkan kategori penilaian proses jawaban, kelompok eksperimen berada pada kategori "Sangat baik" sementara kelompok kontrol berada pada kategori "Baik".
\end{abstract}

Kata kunci: CTL, Kemampuan Representasi, Model Pembelajaran.

\begin{abstract}
The research objectives are to find out the description (1) The mathematical representation ability of students who take mathematics learning with the CTL learning model is better than students who follow the conventional learning model, and (2) the student's answer process related to the ability of mathematical representation taught through CTL and Conventional learning models. This research is a quasi-experimental study with a population of all class IX students at MTs PPMDH Medan in the 2019-2020 academic year. Samples were taken through simple random sampling technique, obtained class IXA as the experimental group with the CTL learning model and class $I X B$ as the control group taught by the conventional learning model (regular). At the end of the study, the two sample classes were given a test using the same instrument which was tested for validity, reliability, level of difficulty and distinguishing power. Data was collected by using the test method and the observation method. The test method was carried out to obtain the final data after being treated in the experimental group and the control group, the data were analyzed by normality test, similarity test of two variances, and hypothesis testing using t-test. The results based on calculations using a one-sided $t$-test obtained t_count $=5.792$ and with a significance of 0.000 .
\end{abstract}


This shows $0.000<0.05$ then $H_{-} O$ is rejected, meaning that the mathematical representation ability of students who follow the CTL learning model is better than students who follow the conventional learning model. These results show that CTL learning has an effect on the ability of mathematical representation. Based on the category of answer assessment, the experimental group was in the "Very good" category while the control group was in the "Good" category.

Keywords: CTL, Representational Ability, Learning Model.

\section{A. Pendahuluan}

Perkembangan ilmu pengetahuan dan teknologi (IPTEK) saat ini semakin pesat. Manusia dituntut memiliki kemampuan berpikir kritis, sistematis, logis, kreatif, bernalar dan kemampuan bekerja sama yang efektif. Salah satu mata pelajaran yang membekali siswa untuk mengembangkan kemampuan-kemampuan tersebut adalah matematika, karena matematika memiliki struktur dan keterkaitan yang kuat dan jelas antar konsepnya sehingga memungkinkan siswa terampil berpikir rasional.

Menurut (As'aril, 2017) Matematika merupakan ilmu universal yang berguna bagi kehidupan manusia dan juga mendasari perkembangan teknologi modern, serta mempunyai peran penting dalam berbagai ilmu disiplin, dan memajukan daya pikir manusia. Matematika diberikan sejak dini di sekolah untuk membekali anak dengan kemampuan berpikir logis, analitis, sistematis, kritis dan kreatif, serta kemampuan berkerja sama.

Matematika dapat membekali semua kemampuan tersebut sebagai modal penting yang diperlukan peserta didik. Kompetensi tersebut di perlukan agar peserta didik dapat memiliki kemampuan, memperoleh, mengelola, dan memanfaatkan informasi untuk bertahan hidup pada keadaan yang selalu berubah, tidak pasti, dan kompetitif. Bahkan pada kurikulum terbaru yaitu kurikulum 2013 matematika adalah pola berpikir pola mengorganisasikan, pembuktian yang logik, serta matematika itu adalah bahasa yang menggunakan istilah yang didefenisikan dengan cermat, jelas, dan akurat, representasinya dengan simbol dan padat.

Menurut National Council of Teacher of Mathematics (Yuniawati, 2011) ada lima standar proses yang perlu dimiliki dan dikuasai peserta didik dalam pembelajaran matematika yaitu: (1) pemecahan masalah; (2) penalaran dan pembuktian; (3) komunikasi; (4) koneksi; (5) representasi. Kelima standar proses tersebut termasuk dalam berpikir matematika tingkat tinggi (high order mathematical thinking) yang perlu di kembangkan dalam pembelajaran matematika.

Pernyataan tersebut menunjukkan bahwa kemampuan representasi matematis siswa yang selama ini dianggap hanya merupakan bahagian kecil dari sasaran pembelajaran, dan tersebar dalam berbagai bahan ajar, ternyata di pandang sebagai suatu proses yang pundamental untuk mengembangkan kemampuan berpikir matematis siswa dan sejajar dengan kemampuan-kemampuan lainnya.

Menurut (Ramziah, 2016) kemampuan representasi matematis merupakan kemampuan yang menuntut siswa untuk dapat membuat suatu model dari suatu masalah ke dalam bentuk baru baik secara verbal, tulisan, grafik, tabel atau-pun gambar.

Kemampuan representasi matematis merupakan salah satu kompetensi yang harus dicapai dalam pembelajaran matematika. Kemampuan representasi matematis diperlukan siswa untuk bepikir matematis dan mengkomunikasikan ide-ide matematika dalam berbagai cara. Hal ini sejalan dengan (Anarulita, 2013) bahwa kemampuan representasi matematis sangat diperlukan dalam matematika, karena untuk memberikan kelancaran siswa dalam membangun konsep dan berfikir matematik serta memiliki kemampuan dan representasi yang kuat dan fleksibel yang dibangun oleh guru melalui representasi matematis.

Berdasarkan hasil observasi yang di lakukan peneliti di kelas IX MTs PPMDH Medan dalam menyelesaikan soal dengan materi prasyarat "Bangun Ruang" yang mengukur kemampuan hasil representasi matematika siswa. Nilai siswa yang rendah sangat dipengaruhi oleh kesulitan dan kesalahan siswa yang ditemukan dalam menjawab soal.

Berdasarkan soal yang diberikan dari 35 orang siswa, sekitar $80 \%$ siswa menjawab 
salah. Dari data tersebut dapat ditarik kesimpulan bahwa sebagian besar kemampuan representasi matematika siswa kelas IX MTs PPMDH Medan masih sangat rendah, hal ini terlihat dari rendahnya nilai yang diperoleh pada soal dalam hal kemampuan representasi matematika. Indikator representasi adalah siswa harus mampu menumbuhkan ide-ide atau gagasan-gagasan dari diri siswa itu sendiri, siswa harus mampu meliputi representasi objek dunia nyata, siswa harus mampu meliputi representasi konkret simbol aritmatika, siswa harus mampu meliputi representasi bahasa lisan/verbal dan representasi gambar atau grafik, dan kemampuan siswa menerjemahkan sifat-sifat dan hubungannya ke dalam masalah matematika ke dalam representasi verbal dan bahasa.

Hasil jawaban siswa menunjukkan bahwa siswa mengalami masalah dan kesulitan dalam memahami soal tersebut. Siswa tidak menuliskan apa yang diketahui dan apa yang ditanya pada soal. Selanjutnya siswa kurang memperhatikan kesesuaian gambarnya yaitu kubus memiliki sifat 12 buah rusuk yang sama panjang, siswa juga tidak dapat menunjukkan yang mana sisi, rusuk dan titik sudutnya, dan yang pasti siswa tidak dapat menghitung jumlah masing-masing sisi,rusuk, dan titik sudutnya.Hal ini diakibatkan siswa sangat jarang sekali dikaitkan dengan kehidupan sehari-hari lewat bantuan alat peraga. Bentuk representasi kubus hanya disajikan dalam bentuk gambar statis oleh guru, yang berakibat ketidak mampuan siswa dalam menjawab soal dengan benar.

Salah satu penyebab rendahnya kemampuan repsentasi siswa di pengaruhi oleh model pembelajaran guru selama ini yaitu, masih menggunakan model pembelajaran konvensional. Hal ini sejalan dengan pendapat (Russefendi, 2018) yang menyatakan bahwa proses pembelajaran matematika selama ini, pada umumnya siswa mempelajari matematika hanya diberi tahu oleh gurunya bukan melalui kegiatan eksplorasi.

Sependapat dengan (Herdiman, 2018) bahwa pada umumnya proses pembelajaran di sekolah sering di-temukan hanya untuk mencapai tujuan tingkat rendah saja yakni dalam mengetahui, memahami dan menggunakan, akan tetapi belum mampu menimbulkan kebiasaan menggunakan kemampuan matematika yang lebih tinggi. Kondisi ini menyebabkan pemahaman siswa terhadap konsep-konsep matematika sangat kurang, sehingga berdampak pada tidak adanya proses dari representasi matematis siswa dalam pembelajaran matematika.

Pembelajaran yang dilakukan selama ini adalah pembelajaran konvensional dimana pada kegiatan pembelajaran guru lebih sering menggunakan metode ceramah, yakni guru menerangkan seluruh isi pelajaran, pengertian atau defenisi, teorema-teorema, penurunan rumus, contoh soal dan penyelesaian semua dilakukan sendiri oleh guru dan diberikan kepada siswa. Sehingga dengan pembelajaran yang selama ini digunakan guru belum mampu mengaktifkan siswa dalam belajar, menemukan ide dan pendapat mereka, dan bahkan enggan siswa dalam bertanya jika mereka belum paham terhadap materi yang disajikan guru.

Menurut (Hudiono, 2015) yang meyatakan bahwa menurut guru, representasi matematis berupa grafik, tabel dan gambar hanya merupakan pelengkap pembelajaran saja dan guru jarang memperhatikan perkembangan kemampuan representasi matematis siswa.

Salah satu pembelajaran yang cocok dan efektif yang dapat mempengaruhi kemampuan representasi matematik siswa adalah pembelajaran dengan model CTL (Contextual Teaching and Learning) yaitu, Konsep belajar yang dapat membantu guru mengaitkan antara materi yang diajarkannya dengan situasi dunia nyata siswa dan mendorong siswa membuat hubungan antara pengetahuan yang dimilikinya dengan penerapan dalam kehidupan mereka sebagai anggota keluarga dan bermasyarakat.

Sebagaimana yang telah dijelaskan oleh Johnson (Handayani, 2007) bahwa pembelajaran kontektual (Contextual Teaching and Learning) merupakan konsep belajar yang membantu guru mengaitkan antara materi yang diajarkannya dengan dunia nyata siswa dan mendorong siswa hubungan antara pengetahuan yang dimilikinya dengan penerapannya dalam kehidupan mereka seharihari.

Menurut (Andriansyah, 2014) pendekatan pembelajaran CTL adalah pendekatan pembelajaran yang menyajikan materi dengan situasi dunia nyata kemudian dipaparkan 
dalam bentuk persoalan/pertanyaan cerita dan memiliki kesulitan tersendiri bagi siswa. Selain itu siswa dituntut untuk me-mahami kaitan antara materi karena bersifat kontekstual untuk menemukan solusi dari permasalahan tersebut.

Dengan melihat penjelasan tersebut, maka dilakukan penelitian mengenai kemampuan representasi matematis melalui pendekatan pembelajaran CTL pada Sub pokok bahasan Bangun Ruang.

\section{B. Metode Penelitian}

Jenis penelitian ini adalah penelitian eksperimen semu sebab kondisi-kondisi siswa tidak dapat dikontrol secara keseluruhan, seperti: persiapan siswa sebelum sekolah, pengerjaan tugas rumah, hubungan siswa dengan orang tua, hubungan siswa dengan lingkungan tempat tinggal, adanya kelas tambahan di luar sekolah dan lain sebagainya. Penelitian ini dilaksanakan di MTs PPMDH Medan.

Populasi penelitian ini adalah seluruh kelas IX di sekolah MTs PPMDH Medan tahun pelajaran 2019-2020 yang terdiri dari 3 kelas, masing-masing berjumlah rata-rata 31 orang.

Pengambilan sampel dalam penelitian ini dilakukan secara acak (simple random sampling) dengan alasan kemampuan siswa di semua kelas bersifat homogeny. Satu kelas diajarkan dengan pembelajaran CTL (Contextual Teaching and Learning), selanjutnya disebut kelas eksperimen dan satu kelas lainnya diajarkan dengan model pembelajaran konvensional, selanjutnya disebut sebagai kelas kontrol.

\section{Hasil dan Pembahasan}

Data yang di analisis adalah hasil tes kemampuan representasi matematika dan proses jawaban siswa. Hasil tes tersebut memberikan informasi tentang kemampuan siswa sebelum, sesudah dilakukan proses pembelajaran baik di kelas eksperimen melalui pembelajaran CTL maupun di kelas control melalui pembelajaran konvensional.

\section{Hasil Tes Kemampuan Awal Matematik Siswa (KAM)}

Tes KAM digunakan untuk mengetahui kesetaraan rerata kelompok eksperimen dan kelompok control, dan untuk mengelompokkan siswa berdasarkan KAM yaitu sangat baik, cukup, dan kurang.

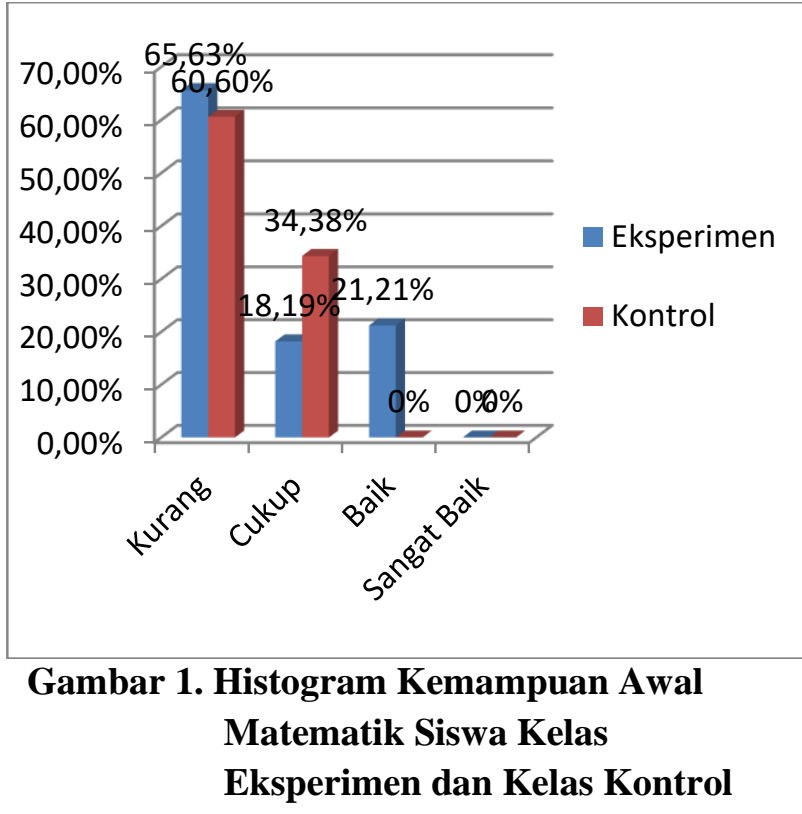

Berdasarkan diagram dapat dilihat bahwa Kemampuan Awal Matematika (KAM) kategori "Sangat baik" untuk kedua pembelajaran diperoleh data $0 \%$ untuk kedua kelompok pembelajaran, KAM kategori "Baik" 0\% untuk kelas control dan 21,21\% untuk kelas eksperimen, KAM kategori "Cukup 34,375\% untuk kelas control dan $18,19 \%$ untuk kelas eksperimen, KAM kategori "Kurang" 60,60\% untuk kelas control dan $65,625 \%$ untuk kelas eksperimen.

\section{Data Kemampuan Representasi Matematik Siswa}

Setelah diketahui kemampuan awal siswa dan membentuk kelompok, kemudian dilakukan pembelajaran dengan menggunakan model. Kelas IXA sebagai kelas eksperimen dengan menggunakan Model CTL dan IXB sebagai kelas control menggunakan model konvensional. 


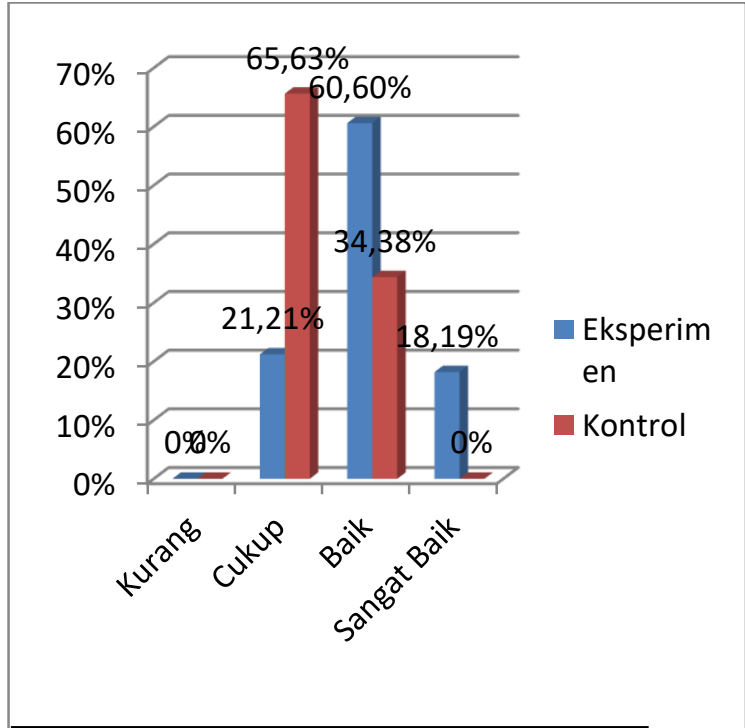

Gambar 2. Histogram Kemampuan

\section{Representasi Matematik Siswa Kelas Eksperimen dan Kelas Kontrol}

Berdasarakan diagram dapat dilihat bahwa kemampuan representasi matematik (KRM) kategori "Sangat Baik" , $0 \%$ untuk kelas kontrol dan 18,19\% untuk kedua kelas eksperimen, KRM kategori "Baik" 34,375 \% untuk kelas kontrol $60,60 \%$ untuk kelas eksperimen, KRM unutuk kategori "Cukup" $65,625 \%$ untuk kelas kontrol. 21,21\% untuk kelas eksperimen sementara presentasi kategori "Kurang" untuk kedua pembelajaran diperoleh data $0 \%$ untuk kedua kelompok pembelajaran.

\section{Analisis Data Penelitian}

Persyaratan dalam analisi kuantitatif adalah asumsi kenormalan, kehomogenan distribusi data yang akan dianalisis.

\section{a. Uji Normalitas}

Uji normalitas data digunakan untuk mengetahui apakah peyebaran data hasil penelitian ini sebaran data yang berditribusi normal atau tidak.

\section{Tabel 1. Hasil Uji normalitas Postest Kemampuan Repersentasi Matematika}

\begin{tabular}{|l|l|l|}
\hline & $\begin{array}{l}\text { Kelas } \\
\text { Eksperimen }\end{array}$ & $\begin{array}{l}\text { Kelas } \\
\text { Kontrol }\end{array}$ \\
\hline $\begin{array}{l}\text { N differe parameters } \\
\text { Normal }\end{array}$ & 33 & 32 \\
Mean & 1187944 & 39.5313 \\
Std Deviation &, 128 & 6.60393 \\
Most ekstreme &,-128 &, 157 \\
$\begin{array}{l}\text { differences Absolut } \\
\text { Positive } \\
\text { Negative } \\
\text { Kolmogrof Smirnof } \\
\text { Sig (2 tailled) }\end{array}$ &, 736 & -.088 \\
\hline
\end{tabular}

*Test distribution is normal

Berdasarkan tabel 1 diatas diperoleh bahwa data postest kelas eksperimen dan kelas kontrol untuk kedua uji, memiliki nilai signifikansi yang lebih besar dari 0.05 yaitu untuk kelas ksperimen kolmogrov - smirnov $(, 651>0,05)$, sementara untuk kelas kontrol kolmogrov - smirnov(,409>,0,05). Maka dapat disimpulkan data postes model pembelajaran CTL dan konvensional berdistribusi normal.

\section{b. Uji Homogenitas}

Uji homogenitas dilakukan dengan menggunakan uji Homogenety of Variances (Levene Statistic) SPSS 19. Kriteria penguji yang digunakan adalah jika nilai significance (sig.) lebih besar dari a $=0,05$ maka sampel berasal dari populasi yang memiliki parians yang homogen.

Tabel 2. Hasil Uji Homogenitas Tes Kemampuan Representasi Matematika Kelompok Kontrol dan Eksperimen

Test of homogeneity of variances

\begin{tabular}{|l|l|l|l|}
\hline $\begin{array}{l}\text { Levene } \\
\text { Statistic }\end{array}$ & Df1 & Df2 & Sig \\
\hline 1,365 & 1 & 64 &, 247 \\
\hline
\end{tabular}

Dari tabel 2 di atas dapat dilihat nilai signifikansi statistika uji Levene $(1,365)$ adalah 0,247 yang berarti lebih besar dari 0,05. Hal ini menunjukkan bahwa kelompok kontrol dan eksperimen memiliki varians yang sama (homogen). 


\section{c. Uji Hipotesis}

Berdasarkan uji hipotesis disimpulkan bahwa nilai $\mathrm{t}$ sebesar 5,792 dan nilai signifikansinya 0,000 . Hal ini menunjukkan bahwa nilai signifikansi 0,000 lebih kecil dari $\mathrm{a}=0,05(0,000<0,05)$ sehingga hipotesis $H_{0}$ dotolak, maka dapat diambil kesimpulan bahwa kemampuan repretasi matematika siswa yang mendapatkan pendekatan pembelajaran CTL (kontekstual) lebih baik daripada siswa yang mendapatkan pembelajaran konvensional/biasa.

Sejalan dengan hasil penelitian (Setianto, 2020) bahwa Model pembelajaran CTL memberikan hasil yang lebih baik dari model pembelajaran RME dan model pembelajaran CTL memberikan hasil yang lebih baik dari model pembelajaran konvensional untuk meningkatkan kemampuan representasi matematis siswa pada sub pokok bahasan kubus dan balok di kelas VIII SMPN 324 Bengkulu Utara.

Begitu pula berdasarkan hasil penelitian (Zanu, 2015) bahwa analisis data untuk menguji hipotesis pada penelitian ini menggunakan uji t. pengujian menunjukkan kemampuan representasi matematik siswa yang diajarkan dengan pendekatan pembelajaran Contextual Teaching And Learning (CTL) lebih tinggi dari pada kemampuan representasi matematik siswa yang diajarkan dengan pendekatan pembelajaran konvensional.

\section{d. Analisis Proses Proses Penyelesaian Jawaban Siswa}

Berdasarkan proses jawaban siswa juga dapat dilihat untuk butir soal nomor 1 rata-rata proses jawaban siswa kelas eksperimen 2,95 dan kelas control 2,32. Untuk butir soal nomor 2 kelas eksperimen 3,54 dan kelas control 2,93, butir soal nomor 3 kelas eksperimen 3,84 dan kelas control 3,42. Butir soal nomor 4 kelas eksperimen 2,49 dan kelas control 1,91. Butir soal nomor 5 kelas eksperimen 2,84 dan kelas control 1,82. Rata-rata keseluruhan proses jawaban siswa kelas eksperimen 3,132 (sangat baik) dan rata-rata keseluruhan proses jawaban siswa control 2,48 (baik).

\section{Kesimpulan dan Saran}

\section{Kesimpulan:}

Berdasarkan hasil analisis data penelitian dan temuan dilapangan yang diuraikan pada bagian sebelumnya dapat disimpulkan bahwa :

a. Nilai $t$ sebesar 5,792 dan nilai signifikansinya 0,000 . Hal ini menunjukkan bahwa signifikansi lebih kecil dari $\alpha=0,05(0,000<0,05)$, dengan kesimpulan dengan menggunakan model CTL dapat meningkatkan kemampuan representasi siswa kelas IX MTs PPMDH Medan Tahun Pembelajaran 2019-2020.

b. Proses jawaban siswa yang terkait kemampuan representasi matematik yang mengikuti pembelajaran CTL dengan nilai rata-rata 3,00 berada pada kategori "sangat baik" sementara siswa yang mengikuti pembelajaran konvensional dengan nilai rata-rata 2,33 berada pada kategori "baik".

\section{Saran}

Berdasarkan kesimpulan dari hasil penelitian, maka peneliti mengajukan beberapa saran yang ditinjukkan kepada berbagai pihak yang berkepentingan dengan hasil penelitian, antara lain:

a. Hendaknya lebih banyak melatih siswa untuk mengekspresikan/memodelkan permasalahan matematika.

b. Hasil dan perangkat peneliti ini dapat dijadikan pertimbangan untuk menggunakan model pembelajaran CTL pada materi bangun ruang sisi lengkung ataupun materi ajar lainnya.

c. Guru dapat menerapkan model pembelajaran CTL.

d. Perlu adanya penelitian lebih lanjut tentang pembelajaran matematika dengan menggunakan pendekatan kontekstual terhadap kemampuan representasi matematis karena penelitian ini masih dalam kategori baik.

\section{E. Daftar Pustaka}

Anarulita, A. A., Multono, M., \& Sunarmi. (2013). Keefektifan Pembelajaran Model Designed Student-Centered Instructional terhadap Kemampuan Represen-tasi Peserta Didik. Unnes Journal of Mathematics Education 2 (3): $60-65$.

Andriansyah, F. (2014). Pengaruh Pendekatan Kontekstual terhadap Kemampuan Representasi Matematis Siswa. Skripsi. 
Universitas Islam Negeri Syarif Hidayatullah Jakarta.

As'aril, (2017). Ilmu Pendidikan Perspektif Kontekstual. Jakarta: Ar.Ruzz Media.

Gitriani, R., Aisah, S., Hendriana, H., \& Herdiman, I. (2018). Pengem-bangan Lembar Kerja Siswa Berbasis Pendekatan Kontekstual pada Materi Lingkaran Untuk Siswa SMP. Jurna; Review Pembelajaran Matematika 3 (1): $40-48$.

Handayani, H. (2015). Pengaruh Pembelajaran Kontekstual Terhadap Kemampuan Pemahaman Dan Representasi Matematis Siswa Sekolah Dasar. Didaktik : Jurnal Pendidikan Guru Sekolah Dasar, ISSN : 24775673 Sekolah Tinggi Keguruan dan Ilmu Pendidikan Subang Volume I Nomor 1, Desember.

Hudiono, Bambang. (2013). Pembudayaan Pendekatan Open-Ended Problem Solving Dalam Pengembangan Daya Representasi Matematik pada Siswa Sekolah Menengah Pertama, Jurnal Pendidikan Dasar Vol 9 No 1.

Ramziah, S. (2016). Peningkatan Kemampuan Representasi Mate-matis Siswa Kelas X2 SMAN 1 Gedung Meneng Menggunakan Bahan Ajar Matriks Berbasis Pendekatan Saintifik. Mosharafa: Jurnal Pendidikan Matematika 5 (2): 138 - 147.

Ruseffendi, E. T. (2018). Dasar-Dasar Matematika Modern dan Kom-puter Untuk Guru. Bandung: Tarsito.

Setianto. E. I., dan Risnanosanti. (2020). Kemampuan Representasi Matematis Siswa SMP melalui Pendekatan Pembelajaran RME dan CTL pada Sub Pokok Bahasan Kubus dan Balok. Indonesian Journal of Mathematics and Natural Sciences Education p-ISSN: 2721-172X e-ISSN: 2721-1746 Vol. 1 No. 3 Th 2020; hal $175-181$
Yuniawati. (2011). Penerapan Pembelajaran Matematika Dengan Strategi React Untuk Meningkatkan Kemampuan Koneksi Dan Representasi Matematik Siswa Sekolah Dasar. ISSN: 1412$565 \mathrm{X}$.

Zanu, S. S. (2015). Pengaruh Pendekatan Pembelajaran Contextual Teaching and Learning Terhadap Kemampuan Representasi Matematik Siswa. (Suatu Penelitian Pada Siswa Kelas VIII SMP Negeri 2 Suwawa). Universitas Negeri Gorontalo. 